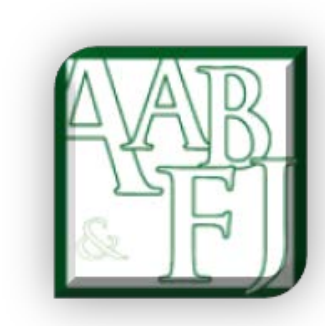

\title{
Fraud Risk Factors and Audit Programme Modifications: Evidence from Jordan
}

Modar Abdullatif1*

\begin{abstract}
This study explores how audit firms in Jordan deal with the presence of fraud risk factors in audit clients. In doing so, the study seeks to explore which fraud risk factors are more important to Jordanian auditors, and how Jordanian auditors consider modifying their audit programmes when fraud risk factors are present in clients. The study uses a structured questionnaire that was administered to senior level auditors in the largest Jordanian audit firms. The findings show that almost all of the 20 fraud risk factors included in the questionnaire were only slightly important (if not unimportant), a finding that is arguably alarming. The perceived importance of modifying the audit programme in the presence of each fraud risk factor was related to the perceived importance of the fraud risk factor itself. However, changes in the nature and extent of audit procedures were more important than changes in the timing of the procedures or the members of the audit team. The most important fraud risk factors were related to the characteristics of management and its attitude towards the audit, while the least important fraud risk factors were related to the difficulties in the client's financial performance. Factor analysis found that the fraud risk factors could be classified into four separate groups. Possible interpretations of the findings were discussed, such as considering the Jordanian business environment characteristics, and the findings were compared to those of extant international studies.
\end{abstract}

Keywords: Fraud risk factors; Audit programmes; Audit firms; Jordan.

JEL Classification: M40.

\footnotetext{
${ }^{1}$ Middle East University, Amman, Jordan

*mod70a@yahoo.com
} 


\section{Introduction}

Auditors are responsible for planning and performing an audit to obtain reasonable assurance about whether financial statements are free from material misstatement. According to the International Standard on Auditing (ISA) no. 240 (and the Statement on Auditing Standards (SAS) no. 99 in the USA), to obtain this reasonable assurance, the auditor should maintain an attitude of professional scepticism, and consider the potential for the existence of fraud in the financial statements. A particular role of the auditor on this issue is to consider the presence of fraud risk factors concerning the audit client, and to respond to the risk of material misstatement due to fraud by designing and performing further audit procedures whose nature, timing, and extent are related to the assessed risk.

Considering fraud risk factors in an audit is important since it is central to what is termed the audit expectations gap. Many studies have found that the users' expectations of audited financial statements about the responsibilities of auditors are different from what auditors consider as their responsibilities (e.g. Humphrey, Moizer \& Turley 1993, in the UK; Monroe \& Woodliff 1994, in Australia; McEnroe \& Martens 2001, in the USA; Abdullatif 2003, in Jordan). A particular difference between views of auditors and users was the issue of the auditor's responsibility about fraud in the financial statements, where auditors were reluctant to accept a responsibility towards detecting fraud. However, under pressure of public expectations and several well-publicised corporate fraud cases, the audit profession in the USA issued the Statement on Auditing Standards (SAS) no. 82 in 1997, followed by SAS no. 99 in 2002, which included the issue of considering fraud risk factors and responding to their existence (Albrecht et al. 2009). The International Federation of Accountants issued ISA no. 240, which also dealt with the issue of fraud risk factors and responding to their existence.

The purpose of this paper is to survey the views of Jordanian auditors about the fraud risk factors that are more important indicators of the possibility of financial statement fraud, and the modifications to audit programmes that are necessary in the presence of each of the selected fraud risk factors. The results are then to be discussed as to whether the characteristics of the Jordanian context may have affected the views of the auditors, and to be compared with the results of the few similar international studies. In doing so, views were surveyed from Jordanian auditors using a questionnaire that asked about the importance of 20 different fraud risk factors, and, for each one, whether its presence would require a change in the amount, nature, or timing of audit procedures, or a change in the assigned audit team by involving more experienced and/or specialised individuals.

Therefore, the main research questions of this paper are:

1. Which fraud risk factors are perceived by Jordanian auditors to be more important?

2. What modifications to audit programmes are perceived by Jordanian auditors to be more important in the presence of fraud risk factors?

The rest of the paper is organised as follows. First, the literature on fraud risk factors and their effects on audit programmes is reviewed, and then the Jordanian auditing environment is discussed. After that, the research design is illustrated, followed by the findings and conclusions.

\section{Auditors' Responsibilities Regarding Fraud}

ISA no. 240 (paragraph 11-a) defines fraud as "an intentional act by one or more individuals among management, those charged with governance, employees, or third parties, involving the use of deception to obtain an unjust or illegal advantage." Fraud can be classified into that generally committed by management (known as fraudulent financial reporting) and that generally committed by employees (known as misappropriation of assets) (Elder, Beasley \& Arens 2010). 
While the primary responsibility for fraud prevention and detection rests with the management of the client and with those charged with governance, the auditor is responsible for planning and performing the audit to ensure that the financial statements are free from material misstatements, whether caused by error or fraud (Soltani 2007). The financial statement audit has inherent limitations and gives only reasonable, rather than absolute, assurance about the freedom of financial statements from material misstatements. However, the audit should be designed to give a reasonable likelihood that fraud will be detected, as auditors are required to approach every stage of the audit with professional scepticism (Porter, Simon \& Hatherly 2008).

In planning and performing an audit, the auditor should be careful when faced with fraud risk factors, which are "events or conditions that indicate an incentive or pressure to commit fraud or provide an opportunity to commit fraud” (ISA no. 240, paragraph 11-b).

There are three key elements that are generally shared by any fraud. These include the existence of a motivation, an opportunity, and a rationalisation of the fraud as acceptable. These elements make up what is generally referred to as the fraud triangle (Cressey 1953). ISA no. 240 draws on this background by listing numerous fraud risk factors related to incentives / pressures, opportunities, and attitudes / rationalisations, relating these factors to the two major types of fraud, which are fraudulent financial statements and misappropriation of assets. Such fraud risk factors may not necessarily mean the existence of fraud in the financial statements, but auditors must take certain actions in the presence of such factors. These actions might include changing the quantity, nature, and timing of audit procedures, and including in the audit team individuals with more experience and/or specialisation.

This study surveys the views of auditors in Jordan about the importance of 20 different fraud risk factors (selected from ISA no. 240 and other relevant literature). It aims to contribute to our knowledge by exploring the views of Jordanian auditors on the importance of particular fraud risk factors and what modifications to audit programmes should be made in the presence of each fraud risk factor, and discussing how the characteristics of the Jordanian context may affect these views. The study also attempts to classify the fraud risk factors into distinctive groups by using factor analysis of the findings.

The Jordanian environment and nature of its audit clients and audit firms suggest the possibility that this background might lead to findings different from those in more-developed countries. In addition, the Jordanian context is very under-researched in the topic of fraud in audited financial statements, and thus this study could potentially make a significant contribution to our knowledge about auditing in Jordan.

\section{Empirical Evidence}

\section{Most Important Fraud Risk Factors}

A small number of studies have been published in the USA discussing which fraud risk factors are the most important according to auditors. The number of published studies on non-USA data is very limited. In a study in the USA, Hackenbrack (1993) found that auditors of larger clients generally placed more emphasis on fraud opportunities when compared to auditors of smaller clients, who placed more emphasis on incentives. The main opportunities emphasised included domination of the company by one strong individual, and inadequate use of the budgeting process and interim financial statements. On the other hand, the main incentives emphasised included a narrow margin of compliance with restrictive debt covenants and a strong pressure to increase the price of the company's shares (Hackenbrack 1993). 
Other studies based on USA data include that of Apostolou et al. (2001), who surveyed the views of auditors on the relative importance of a number of fraud risk factors. They found that fraud risk factors involving management characteristics and influence over the control environment were significantly more important than factors related to financial stability and industry conditions. Also, Moyes (2008) surveyed views of CPAs over the effectiveness of fraud risk factors in detecting fraudulent financial reporting. He found that fraud risk factors related to attitudes / rationalisation were perceived as more effective compared to those related to opportunities or incentives / pressures. The most important fraud risk factors reported were known histories of violations of security laws or allegations of fraud against the client or its senior management or board members, and management attempts to influence the scope of the auditor's work. Surveys of internal auditors (Gramling \& Myers 2003; Moyes, Lin \& Landry 2005) also reported a tendency to perceive fraud risk factors related to attitudes and rationalisation as relatively high in importance when compared to other factors.

In a study of auditors in Hong Kong, Abdul Majid, Gul and Tsui (2001) reported that the most important fraud risk factors were difficult-to-audit transactions, misstatements in prior audits, indicators of going concern problems, management's attitude to financial reporting and management operating style. In addition, a Malaysian survey of auditors by Smith et al. (2005) reported that the most important fraud risk factors were operating and financial stability issues (such as high dependence on debt and deteriorating financial position). These were followed by managerial characteristics (such as attitude about internal control and known history of law violations), while industry conditions ranked lowest.

In summary, while the small number of extant studies on the issue of the relative importance of fraud risk factors limits the ability to generalise the results or draw reliable conclusions, it shows the possibility that the contextual background of the study might affect its results. For example, while the USA-based studies found that the most important fraud risk factors were those related to managerial characteristics, studies in Hong Kong and Malaysia found more emphasis on fraud risk factors related to the nature of the client or its operating and financial stability. This paper seeks to explore the issue of fraud risk factors and their importance and classification in a developing country (Jordan) with a different contextual background to the countries mentioned above, and to interpret the results taking into account this difference.

\section{The Effects of Fraud Risk Factors on Audit Programmes}

Zimbelman (1997) found that separately assessing fraud risk factors influences attention to fraud cues and audit planning decisions. He found that the influence on audit programmes is in budgeting more hours to the audit rather than changing the nature of audit plans. In a replication of this study after SAS no. 82 was issued, Glover et al. (2003) found that auditors became more sensitive to fraud risk factors after the issuance of the standard, but that the modification in audit plans was in increasing the extent of audit tests rather than changing the nature of these tests. Makkawi and Schick (2003) reported similar findings of increasing the extent of audit tests as a result of the presence of fraud risk factors.

Mock and Turner (2005) reported evidence that after the issuance of SAS no. 82, audits became more risk-adjusted and that the adjustments included modifying the nature, extent, and/or timing of audit procedures, in addition to the possibility of assigning more experienced audit team members. They also found that modifications of audit programmes are related to the type and number of fraud risk factors and to the overall client risk.

Graham and Bedard (2003) surveyed Big Five auditors and found that most audit clients exhibit one or more fraud risk factors from more than one general reason, including industry conditions, management integrity, internal control quality and financial condition. They also found that the nature of the audit test planned varies by the risk factor type. 
Blay, Sneathen and Kizirian (2007) analysed the association between auditors' preliminary assessment of fraud and going concern risk and the planning and performance of the audit. They found that fraud risk increases the persuasiveness of audit evidence gathered, and results in later gathering of the evidence. Therefore, the result is a shift in audit effort, but not an increase in the total time expended.

In a survey of seven large auditing firms’ practices (including the then Big Five), Shelton, Whittington and Landsittel (2001) reported differences among the firms in the timing and methods of fraud risk assessments. In addition, while all firms provided guidance on responses to fraud risk that generally included modifying the nature, timing and extent of audit procedures with general regard to the $S A S$ no. 82 requirements, a few firms gave guidance additional to that required by SAS no. 82 (including even more fraud risk factors). Also, firms differed significantly in their guidance on issues such as considering resignation from engagement and considering consulting a fraud specialist.

As for some particular methods that may be employed for modifying audit programmes, Hoffman and Zimbelman (2009) found that in cases of a high fraud risk setting, both strategic reasoning and brainstorming lead to more effective modifications to standard audit procedures. Consistent with these findings, Carpenter (2007), in a study of the impact of SAS no. 99, found that group brainstorming of the audit team is useful in improving the quality of ideas of dealing with fraud, and that it leads to significantly increasing the fraud risk assessment.

On using a checklist to assess fraud risk factors, Asare and Wright (2004) found that auditors who used standard audit programmes and standard risk checklists were less effective in designing a programme to deal with fraud than those who did not use the checklist tool, and that they were also less likely to consult fraud experts. They concluded that rather than using standard audit tools, auditors should use a more strategic reasoning approach when fraud risk is elevated.

According to Hogan et al. (2008), most of the research findings suggest that the use of checklists is a relatively poor idea that may actually restrict the auditors' generation of ideas. Hogan et al. (2008) also conclude that research findings support using regression models (see Bell \& Carcello 2000) or expert system aids (see Eining, Jones \& Loebbecke 1997) to improve fraud risk assessment.

The results of the above-mentioned studies suggest mixed results as to whether modifications to the audit programme in the presence of a high fraud risk client include a change in the nature, timing or extent of audit procedures, or in the audit team members. This paper seeks to contribute to our knowledge by studying this issue in a different environment and background, and by relating the suggested modifications individually to each fraud risk factor.

\section{Auditing in Jordan}

Since Jordan's independence in 1946, the Jordanian audit profession has increased significantly in size. Currently, there are about 300 audit firms in Jordan, ranging from a majority of very small audit firms to a minority of firms who are significantly larger and deal with much larger clients, including multinationals operating in Jordan. Several Jordanian audit firms have some sort of affiliation with an international audit firm, including the Big Four. Many of these Jordanian firms have currently achieved a full membership in their international audit firm groups. This obliges the Jordanian firm to follow its international audit firm's audit methodology and detailed programmes (as much as required by the international firm), and to be scrutinised by that firm for quality control (Abdullatif \& Al-Khadash 2010).

Governance of the audit profession in Jordan is mainly by the public sector, through a high commission for the auditing profession headed by the Minister of Industry and Trade, and including representatives of several government agencies and some practising auditors. The auditors themselves 
have their own private sector association - the Jordan Association of Certified Public Accountants (JACPA), which may propose suggested regulations to the high commission. The high commission is responsible for issuing the audit laws and regulations that are approved by Parliament.

According to the World Bank (2004), this system of governance has several deficiencies, include weak monitoring and enforcement by JACPA on audit firms' application of the International Standards on Auditing (ISA) (most recent 2012) on their audits. Other problems with the audit profession in Jordan include poor independence due to heavy reliance on personal relations and few clients, poor emphasis on the effect of related parties in the dominance of a family business system, poor use of some audit evidence, and poor continuous education of auditors (World Bank 2004).

While the number of publicly listed shareholding Jordanian companies is about 200, the entities that are legally required to have their financial statements audited exceed 30,000 (Al-Khadash 2010). These include thousands of limited liability companies (including all foreign company branches operating in Jordan) and large partnerships (with a minimum capital of JD 100,000 - approximately USD 141,000). In fact, some of these other audit clients are significantly larger than many public shareholding companies. Public shareholding companies are required to prepare their annual financial statements using the International Financial Reporting Standards (IFRS) (most recent 2013), and to have them audited by audit firms under the ISA, a regulation in force since 1998.

Most of the audit clients in Jordan are closely-held firms, especially family-dominated. Limited separation of management and ownership exists, and the most senior positions in management are given to the largest shareholders and their relations. This affects the application of the ISA by audit firms (Abdullatif \& Al-Khadash 2010), and reduces the level of protection available for minority owners (Daniels, Radebaugh \& Sullivan 2011). In addition, while Jordanian public shareholding companies are required to establish audit committees, the effectiveness of these committees may be limited under such a governance system (Abdullatif 2006). This is because executive and nonexecutive members of boards of directors are likely to have strong relations, and because audit committee members are not required to be financially literate, let alone be financial experts. According to Abdullatif and Al-Khadash (2010), such a corporate governance system, where senior executive managers (themselves major shareholders) are not accountable to minor shareholders, is likely to affect the nature of the application of the audit function and lower its quality (and therefore lower audit fees) given the lower agency costs involved.

Theories of demand on auditing suggest that a high quality audit is demanded in order to reduce agency costs of the conflict of interest between managers and owners (Soltani 2007) and to improve investment decisions by reducing investment risk (Wallace 1991). Also, auditors have to perform a good audit to protect themselves from loss, since a demand exists for audits for investors to potentially recover losses from auditors' deep pockets (Wallace 2004). While such arguments may have some logic in capital market systems, in Jordan the case may be different. This is because costs of conflicts between managers and shareholders are limited (limited separation of roles, coupled with weak minority shareholders), information is generally available to major shareholders from insider sources, and litigation against auditors is limited. This is likely to lower demand for high quality external audits (Abdullatif \& Al-Khadash 2010).

A low demand for auditing is likely to lead to relatively low audit fees - as is the case in Jordan, compared with more-developed and neighbouring countries. Although this has eased recently due to the increased number of international audit clients and the introduction of more demanding regulations on auditing, it still remains a very important issue concerning the resulting quality of external auditing services in Jordan (Abdullatif \& Al-Khadash 2010). Also, the fact that most audit clients are familyowned and private usually leads to lower audit fees (Hay, Knechel \& Wong 2006). Another explanation of low audit fees is arguably the fact that with about 300 audit firms of several sizes practising in Jordan, a severe competition on price exists, especially when a high-quality audit service 
is not strongly demanded. Also, the level of litigation against auditors in Jordan is relatively low and lacks serious penalties or other negative consequences (Abdullatif \& Al-Khadash 2010).

\section{The Research Method}

The research method used in this study was a questionnaire survey. This method was selected to gather the views of the largest possible number of individuals on the research topic. The questionnaire surveyed the views of auditors on the importance of 20 potential fraud risk factors and the modifications to audit programmes necessary in the presence of any of these factors. Suggested modifications included changes in the nature of audit procedures to be used, the quantity of these procedures, the timing of these procedures, and the need for involving more experienced and/or specialised individuals in the audit team. It was explicitly emphasised that what was required was the respondent's personal views, which may or may not conform to what is included in regulations or professional standards. An additional section was added to provide information on the personal background of the respondents, an issue that can be used for further analysis of the results.

A seven-choice Likert scale was used in the questionnaire, with strong agreement on the issue in question being assigned a value of 7 , and strong disagreement being assigned a value of 1 . The choice of 7 alternatives (rather than, for example, 5) was made because the questionnaire aimed at ranking many items, and giving more alternatives was expected to make ranking the results and differences between items clearer. The face validity of the questionnaire was tested by having it reviewed by accounting academics. These individuals assessed the content and wording of the questionnaire, and their comments were included in revising it.

The study covered the 12 largest audit firms in Jordan, 10 of which have international affiliations, including affiliations with each of the Big Four audit firms. The study population was defined as auditors from the 12 firms, who have experience in participation in audit programme design and risk analysis. Therefore, audit firms were asked to distribute the questionnaires to auditors of middle or high ranks. However, some audit firms claimed that some juniors with relative experience had some role to play in risk analysis and audit programme design, and in these firms such individuals were included in the study if the firm claimed that they participated in these tasks. According to its definition, the full study population was surveyed.

The questionnaires (in Arabic) were distributed personally by the researcher to the audit firms, and then collected later. This distribution method was chosen because it is likely to generate a significantly higher response rate, compared to mail or email distribution, without significantly impairing the reliability of the responses, since the researcher did not interfere with the respondents or otherwise affect them when they completed the questionnaire (Siam \& Abdullatif 2011). The need for a reasonable response rate is emphasised given the relatively small size of the study population.

A total of 161 questionnaires, covering the full study population, were distributed to auditors from the 12 audit firms. The number of usable responses received was 92, giving a response rate of about 57\%, a good response rate for such studies in Jordan, especially since higher-ranked auditors were targeted. Attempts to increase the number of respondents through adding less-experienced auditors was seen as unjustified, as these individuals lack sufficient experience, while the addition of other audit firms was arguably unacceptable since they are generally significantly smaller than the selected firms, and therefore likely to lack structured audit programmes and risk analysis procedures. 
Table 1

Personal Background of Respondents

\begin{tabular}{|c|c|c|c|}
\hline DEMOGRAPHIC VARIABLE & FREQUENCY & DEMOGRAPHIC VARIABLE & FREQUENCY \\
\hline Gender of respondent & & Job title of respondent & \\
\hline Male & 83 & Junior auditor & 21 \\
\hline Female & 8 & Semi-senior auditor & 26 \\
\hline \multirow[t]{2}{*}{ TOTAL } & 91 & Senior auditor & 25 \\
\hline & & Supervisor or assistant manager & 6 \\
\hline Age of respondent & & Manager & 8 \\
\hline Below 25 years & 36 & Partner & 6 \\
\hline 25 to 30 years & 38 & TOTAL & 92 \\
\hline 31 to 40 years & 12 & & \\
\hline 41 to 50 years & 3 & $\begin{array}{l}\text { Whether the respondent has an } \\
\text { international professional } \\
\text { certificate in auditing }\end{array}$ & \\
\hline Above 50 years & 3 & Yes & 17 \\
\hline \multirow[t]{2}{*}{ TOTAL } & 92 & No & 73 \\
\hline & & TOTAL & 90 \\
\hline \multicolumn{4}{|l|}{$\begin{array}{l}\text { Experience of respondent in external } \\
\text { auditing }\end{array}$} \\
\hline Below 5 years & 63 & $\begin{array}{l}\text { Whether the respondent works } \\
\text { for an audit firm with an } \\
\text { international affiliation }\end{array}$ & \\
\hline 5 to 10 years & 15 & Yes - Big Four audit firm & 34 \\
\hline 11 to 15 years & 7 & Yes - Non-Big Four audit firm & 46 \\
\hline 16 to 20 years & 1 & No & 12 \\
\hline Above 20 years & 5 & TOTAL & 92 \\
\hline \multirow[t]{2}{*}{ TOTAL } & 91 & & \\
\hline & & $\begin{array}{l}\text { Whether the respondent has } \\
\text { had audit experience outside } \\
\text { Jordan }{ }^{2}\end{array}$ & \\
\hline $\begin{array}{ll}\text { Highest achieved } & \text { academic } \\
\text { qualification of respondent } & \end{array}$ & & Yes - in Arab countries & 8 \\
\hline Secondary school degree or less & 0 & Yes - in Europe & 0 \\
\hline Community college degree & 0 & Yes - in North America & 2 \\
\hline First university degree & 80 & Yes - in countries not listed above & 0 \\
\hline Postgraduate diploma degree & 1 & No & 83 \\
\hline Master degree & 10 & TOTAL & 93 \\
\hline Doctorate degree & 1 & & \\
\hline TOTAL & 92 & & \\
\hline
\end{tabular}

\footnotetext{
${ }^{2}$ Respondents had the option of more than one answer for this question, but only one respondent used it.
} 


\section{Findings}

\section{Reliability of the Results}

The Cronbach's Alpha method was used for testing the questionnaire's reliability. This method is used to test a questionnaire's internal consistency by correlating the responses to its questions with each other (Saunders, Lewis \& Thornhill 2012). Cronbach's Alpha was found to be 96.5\%, a figure significantly higher than the minimum acceptable value of 60\% (Zikmund et al. 2010). This means that the reliability of the questionnaire's results is acceptable.

\section{Personal Background of the Respondents}

Table 1 shows the characteristics of the respondents to the questionnaire. Most of the respondents were male, as expected in the Jordanian context where females are unlikely to choose a career in auditing or to stay in it for long, given its high time and effort demands. All of the respondents had at least a first university degree, indicating that they are reasonably educated in accounting and auditing issues. A relatively large percentage of respondents were in the middle (senior and semi-senior) or low (junior) ranks in their firms, a fact that is also reflected in their reported age and audit experience. While the researcher would have preferred to have a more balanced respondent distribution in terms of job rank and experience, it is known that audit partners and managers are significantly fewer in numbers, and arguably much less likely than lower-ranked auditors to respond to questionnaire surveys. Some of the auditors surveyed had international certificates in auditing, and most of them were working for an internationally affiliated Jordanian audit firm.

\section{Importance of Fraud Risk Factors}

Table 2 shows the ranking of the 20 fraud risk factors included in the questionnaire according to the mean responses for each issue, thus reflecting the views of auditors in Jordan about the relative importance of each of the fraud risk factors included. Standard deviations are provided between brackets. It can be seen from the results reported in the table that almost all of the fraud risk factors were seen by auditors as slightly important at most, while some were even seen as unimportant. This may be interpreted from a Jordanian perspective as a result of poor demand for auditing and the nature of audit clients in Jordan, where most are closely-held companies. This environment makes the risk of the occurrence of financial statement fraud relatively lower (although certainly not eliminated) than that of, for example, the Anglo-American countries where most companies have a general separation between the ownership and management of companies. Coupled with this is the argument that the risk of litigation facing audit firms in Jordan is relatively low, and the penalties and negative consequences of audit failure are also low, thus implying that there is reduced care in dealing with fraud risk factors. This applies to many companies in Jordan, whether closely-held or more widely-owned. 
Table 2

Importance of Fraud Risk Factors and their Effects on Audit Programmes

\begin{tabular}{|c|c|c|c|c|c|c|}
\hline Rank & Fraud risk factor & $\begin{array}{l}\text { Mean for } \\
\text { relative } \\
\text { importance } \\
\text { of factor }\end{array}$ & $\begin{array}{c}\text { Increasing } \\
\text { quantity of } \\
\text { audit } \\
\text { procedures }\end{array}$ & $\begin{array}{l}\text { Changing } \\
\text { nature of } \\
\text { audit } \\
\text { procedures }\end{array}$ & $\begin{array}{l}\text { Changing } \\
\text { timing of } \\
\text { audit } \\
\text { procedures }\end{array}$ & $\begin{array}{l}\text { Changing } \\
\text { audit team }\end{array}$ \\
\hline 1 & $\begin{array}{l}\text { The members of the client's management have a known } \\
\text { history of violations of laws and/or allegations of fraud }\end{array}$ & $\begin{array}{c}\mathbf{6 . 0 9} \\
(1.320) \\
\end{array}$ & $\begin{array}{c}\mathbf{6 . 0 1} \\
(1.327)\end{array}$ & $\begin{array}{c}\mathbf{6 . 0 1} \\
(1.301)\end{array}$ & $\begin{array}{c}5.55 \\
(1.560)\end{array}$ & $\begin{array}{c}5.56 \\
(1.538)\end{array}$ \\
\hline 2 & $\begin{array}{l}\text { The client's management deliberately puts restrictions on the } \\
\text { external audit's scope and does not provide the external } \\
\text { auditor with information he/she deems necessary }\end{array}$ & $\begin{array}{c}\mathbf{6 . 0 1} \\
(1.541)\end{array}$ & $\begin{array}{c}5.92 \\
(1.280)\end{array}$ & $\begin{array}{c}\mathbf{6 . 0 0} \\
(1.222)\end{array}$ & $\begin{array}{c}5.43 \\
(1.515)\end{array}$ & $\begin{array}{c}5.33 \\
(1.826)\end{array}$ \\
\hline 3 & $\begin{array}{l}\text { The client's management is dominated by a single person or } \\
\text { a small group who are able to override existing internal } \\
\text { controls }\end{array}$ & $\begin{array}{c}5.71 \\
(1.575)\end{array}$ & $\begin{array}{c}5.73 \\
(1.421)\end{array}$ & $\begin{array}{c}5.63 \\
(1.480)\end{array}$ & $\begin{array}{c}4.94 \\
(1.688)\end{array}$ & $\begin{array}{c}4.90 \\
(1.784)\end{array}$ \\
\hline 4 & $\begin{array}{l}\text { The client's accounting information system and internal } \\
\text { control system are weak and ineffective }\end{array}$ & $\begin{array}{c}5.40 \\
(1.543)\end{array}$ & $\begin{array}{c}\mathbf{5 . 6 0} \\
(1.347)\end{array}$ & $\begin{array}{c}5.55 \\
(1.306)\end{array}$ & $\begin{array}{c}4.94 \\
(1.496)\end{array}$ & $\begin{array}{c}5.03 \\
(1.771)\end{array}$ \\
\hline 5 & $\begin{array}{l}\text { The client's management is not cooperative on financial } \\
\text { reporting disputes with the external auditor }\end{array}$ & $\begin{array}{c}5.34 \\
(1.651)\end{array}$ & $\begin{array}{c}5.50 \\
(1.414)\end{array}$ & $\begin{array}{c}5.48 \\
(1.295)\end{array}$ & $\begin{array}{c}4.95 \\
(1.646)\end{array}$ & $\begin{array}{c}5.00 \\
(1.692)\end{array}$ \\
\hline 6 & $\begin{array}{l}\text { Monitoring by the board of directors and audit committee on } \\
\text { the client's internal control and financial reporting is weak } \\
\text { and ineffective }\end{array}$ & $\begin{array}{c}5.29 \\
(1.463)\end{array}$ & $\begin{array}{c}5.50 \\
(1.309)\end{array}$ & $\begin{array}{c}5.27 \\
(1.322)\end{array}$ & $\begin{array}{c}\mathbf{4 . 7 6} \\
(1.574)\end{array}$ & $\begin{array}{c}4.74 \\
(1.676)\end{array}$ \\
\hline 7 & $\begin{array}{l}\text { The client made significant and high monetary value } \\
\text { transactions with its related parties }\end{array}$ & $\begin{array}{c}5.17 \\
(1.315)\end{array}$ & $\begin{array}{c}5.18 \\
(1.403)\end{array}$ & $\begin{array}{c}5.40 \\
(1.250)\end{array}$ & $\begin{array}{c}4.40 \\
(1.505)\end{array}$ & $\begin{array}{c}\mathbf{4 . 4 8} \\
(1.797)\end{array}$ \\
\hline 8 & $\begin{array}{l}\text { The client's executive management bonuses are tied to } \\
\text { achieving difficult operational profit or share price targets }\end{array}$ & $\begin{array}{c}5.06 \\
(1.725) \\
\end{array}$ & $\begin{array}{c}4.83 \\
(1.704) \\
\end{array}$ & $\begin{array}{c}5.09 \\
(1.466)\end{array}$ & $\begin{array}{c}4.50 \\
(1.749)\end{array}$ & $\begin{array}{c}4.32 * \\
(1.889)\end{array}$ \\
\hline 9 & $\begin{array}{l}\text { The client's management insists on achieving difficult } \\
\text { targets regarding profits or share prices or market share }\end{array}$ & $\begin{array}{c}5.04 \\
(1.514)\end{array}$ & $\begin{array}{c}5.10 \\
(1.415)\end{array}$ & $\begin{array}{c}5.06 \\
(1.505) \\
\end{array}$ & $\begin{array}{c}4.42 \\
(1.590) \\
\end{array}$ & $\begin{array}{c}4.17 * \\
(1.747)\end{array}$ \\
\hline 10 & $\begin{array}{l}\text { The client's financial reporting includes a large degree of use } \\
\text { of estimates and personal judgement }\end{array}$ & $\begin{array}{c}5.02 \\
(1.568)\end{array}$ & $\begin{array}{c}5.01 \\
(1.482) \\
\end{array}$ & $\begin{array}{c}5.18 \\
(1.403) \\
\end{array}$ & $\begin{array}{c}4.27 * \\
(1.617) \\
\end{array}$ & $\begin{array}{c}4.37 \\
(1.741)\end{array}$ \\
\hline 11 & $\begin{array}{l}\text { The client made a lot of materially significant transactions } \\
\text { that do not appear to relate to its normal business activities }\end{array}$ & $\begin{array}{c}4.85 \\
(1.665)\end{array}$ & $\begin{array}{c}5.19 \\
(1.385)\end{array}$ & $\begin{array}{c}5.13 \\
(1.463) \\
\end{array}$ & $\begin{array}{c}4.39 \\
(1.580)\end{array}$ & $\begin{array}{c}\text { 4.24* } \\
(1.875) \\
\end{array}$ \\
\hline 12 & $\begin{array}{l}\text { The client's management does not care to support ethical } \\
\text { values in the organisation, and does not communicate the } \\
\text { importance of ethical values to employees }\end{array}$ & $\begin{array}{c}4.72 \\
(1.696)\end{array}$ & $\begin{array}{c}\mathbf{4 . 6 7} \\
(1.579)\end{array}$ & $\begin{array}{c}\mathbf{4 . 8 2} \\
(1.394)\end{array}$ & $\begin{array}{c}\text { 4.33* } \\
(1.610)\end{array}$ & $\begin{array}{c}\text { 4.00* } \\
(1.768)\end{array}$ \\
\hline 13 & $\begin{array}{l}\text { The client's business transactions are complex and require } \\
\text { complex and unclear accounting treatments }\end{array}$ & $\begin{array}{c}4.70 \\
(1.754)\end{array}$ & $\begin{array}{c}\mathbf{5 . 1 1} \\
(1.512)\end{array}$ & $\begin{array}{c}\mathbf{5 . 4 0} \\
(1.381)\end{array}$ & $\begin{array}{c}4.42 \\
(1.565)\end{array}$ & $\begin{array}{c}\mathbf{5 . 1 6} \\
(1.715)\end{array}$ \\
\hline 14 & $\begin{array}{l}\text { The client suffers high and recurring operating losses that } \\
\text { significantly threaten its future as a going concern }\end{array}$ & $\begin{array}{c}4.69 \\
(1.651)\end{array}$ & $\begin{array}{c}4.89 \\
(1.518)\end{array}$ & $\begin{array}{c}5.05 \\
(1.346)\end{array}$ & $\begin{array}{c}4.44 \\
(1.560)\end{array}$ & $\begin{array}{c}4.55 \\
(1.815)\end{array}$ \\
\hline 15 & $\begin{array}{l}\text { The members of the client's executive management own a } \\
\text { high percentage of the client's shares }\end{array}$ & $\begin{array}{c}4.63 \\
(1.619)\end{array}$ & $\begin{array}{c}4.56 \\
(1.515)\end{array}$ & $\begin{array}{c}4.68 \\
(1.498)\end{array}$ & $\begin{array}{c}4.27 * \\
(1.543)\end{array}$ & $\begin{array}{c}\text { 4.11* } \\
(1.748)\end{array}$ \\
\hline
\end{tabular}




\begin{tabular}{|c|c|c|c|c|c|c|}
\hline 16 & $\begin{array}{l}\text { The client faces significant difficulties in meeting the } \\
\text { conditions of debt covenants related to financial figures and } \\
\text { ratios }\end{array}$ & $\begin{array}{c}4.59 \\
(1.789)\end{array}$ & $\begin{array}{c}4.63 \\
(1.448)\end{array}$ & $\begin{array}{c}4.92 \\
(1.424)\end{array}$ & $\begin{array}{c}4.24 * \\
(1.567)\end{array}$ & $\begin{array}{c}4.34 * \\
(1.728)\end{array}$ \\
\hline 17 & $\begin{array}{l}\text { The client suffers recurring negative operating cash flows } \\
\text { that significantly threaten its future as a going concern }\end{array}$ & $\begin{array}{c}4.54 \\
(1.471) \\
\end{array}$ & $\begin{array}{c}4.82 \\
(1.299)\end{array}$ & $\begin{array}{c}4.95 \\
(1.124)\end{array}$ & $\begin{array}{c}4.15^{*} \\
(1.326)\end{array}$ & $\begin{array}{c}4.17 * \\
(1.554)\end{array}$ \\
\hline 18 & $\begin{array}{l}\text { The client faces significant difficulties in meeting its own } \\
\text { previously published management expectations of profits or } \\
\text { share price or market share }\end{array}$ & $\begin{array}{c}4.50 \\
(1.711)\end{array}$ & $\begin{array}{c}4.61 \\
(1.520)\end{array}$ & $\begin{array}{c}4.65 \\
(1.447)\end{array}$ & $\begin{array}{c}4.24^{*} \\
(1.531)\end{array}$ & $\begin{array}{c}\text { 4.13* } \\
(1.800)\end{array}$ \\
\hline 19 & $\begin{array}{l}\text { The client faces significant difficulties in meeting the } \\
\text { conditions required for listing in the financial market its } \\
\text { shares are listed on }\end{array}$ & $\begin{array}{c}4.20 * \\
(1.874)\end{array}$ & $\begin{array}{c}\mathbf{4 . 1 7 *} \\
(1.653)\end{array}$ & $\begin{array}{c}\mathbf{4 . 3 8} \\
(1.669)\end{array}$ & $\begin{array}{c}3.87 * \\
(1.625)\end{array}$ & $\begin{array}{c}\text { 4.16* } \\
(1.872)\end{array}$ \\
\hline 20 & $\begin{array}{l}\text { The client suffers high competition and a declining market } \\
\text { share }\end{array}$ & $\begin{array}{c}3.83 * \\
(1.674)\end{array}$ & $\begin{array}{c}4.25 * \\
(1.367)\end{array}$ & $\begin{array}{c}4.39 \\
(1.279)\end{array}$ & $\begin{array}{c}3.53 \\
(1.575)\end{array}$ & $\begin{array}{c}3.90 * \\
(1.847)\end{array}$ \\
\hline
\end{tabular}

* The Mean is not statistically significantly different from the "neutral" value 4 at the 5\% significance level. 
Another possible explanation for the low reported importance of fraud risk factors may be related to the relatively low audit fees in Jordan, compared to the cost of performing an audit. This may make auditors consider fraud risk factors to be less important and therefore needing to be dealt with less extensively. Such reasoning might lead auditors to compromise on performing some essential audit procedures in order to save cost, as competition may prevent them from being able to increase their fees.

Finally, auditors in Jordan may possibly lack sufficient and appropriate training and continuous learning regarding the application of auditing standards, especially in the area of dealing with fraud risk. This might lead to the perceived low importance of most fraud risk factors included in this study.

As for the ranking of the fraud risk factors according to the views of the Jordanian auditors, it seems that the most important fraud risk factors were those related to the nature of management and its operating style. Factors such as known histories of fraud allegations or law violations, in addition to deliberate restriction of audit scope, were reported as having the highest relative importance. While such issues are generally important as indications of possible existence of fraud, it is interesting to see that other management and governance factors, such as domination of management by one person, weak monitoring by those charged with governance, and weak accounting and internal control systems were perceived as not having a very high importance. Even less important were factors such as financial reporting disputes with management, management bonuses tied to aggressive targets, and the existence of significant transactions with related parties or transactions with a large degree of personal judgement and estimation. In addition, factors such as the existence of abnormal transactions and the ownership of most of the client's shares by senior executive management members were also seen as almost unimportant.

These results may be attributed to the argument that many of the fraud risk factors perceived as relatively low in importance are common to many audit clients in Jordan, and therefore they would not surprise and alarm auditors to a large degree. This is in addition to the argument of a possible lack of sufficient knowledge and training by the auditors. However, this issue needs to be cared for by Jordanian audit firms and the international audit firms with which they are affiliated, since these factors are well known internationally to cause significant concern about possible fraud existence. A similar argument can be made about the fraud risk factors related to the deteriorating financial conditions of the audit client. These factors were generally perceived by the auditors as unimportant or least important - an issue clearly contradicting professional scepticism.

In summary, it seems that the fraud risk factors seen as having the most importance were those related to the management and governance of the client, compared with factors related to the nature of the client's business or its financial conditions. This may be because the auditors perceive that management and governance issues directly affect the audit conduct to a higher degree than issues related to the client's nature or its financial conditions.

An obvious difference between the results of this study and those of other extant international studies was not in the nature of the ranking of fraud risk factors' importance itself, but rather in the degree of reported importance, with most fraud risk factors listed in this study seen as low in importance. 
Table 3

Factor Analysis Results: Rotated Component Matrix

\begin{tabular}{|c|c|c|c|c|c|}
\hline & Fraud risk factor & $\begin{array}{c}\text { Component } \\
1\end{array}$ & $\begin{array}{c}\text { Component } \\
2\end{array}$ & $\begin{array}{c}\text { Component } \\
3\end{array}$ & $\begin{array}{c}\text { Component } \\
4\end{array}$ \\
\hline 1 & $\begin{array}{l}\text { The members of the client's management have a } \\
\text { known history of violations of laws and/or allegations } \\
\text { of fraud }\end{array}$ & 0.812 & 0.277 & 0.158 & 0.070 \\
\hline 2 & $\begin{array}{l}\text { The client's management deliberately puts restrictions } \\
\text { on the external audit's scope and does not provide the } \\
\text { external auditor with information he/she deems } \\
\text { necessary }\end{array}$ & 0.837 & 0.298 & 0.194 & 0.066 \\
\hline 3 & $\begin{array}{l}\text { The client's management is dominated by a single } \\
\text { person or a small group who are able to override } \\
\text { existing internal controls }\end{array}$ & 0.694 & 0.140 & 0.135 & 0.218 \\
\hline 4 & $\begin{array}{l}\text { The client's accounting information system and } \\
\text { internal control system are weak and ineffective }\end{array}$ & 0.699 & -0.182 & 0.213 & 0.284 \\
\hline 5 & $\begin{array}{l}\text { The client's management is not cooperative on } \\
\text { financial reporting disputes with the external auditor }\end{array}$ & 0.776 & 0.352 & 0.006 & 0.051 \\
\hline 6 & $\begin{array}{l}\text { Monitoring by the board of directors and audit } \\
\text { committee on the client's internal control and } \\
\text { financial reporting is weak and ineffective }\end{array}$ & 0.673 & -0.004 & 0.070 & 0.137 \\
\hline 7 & $\begin{array}{l}\text { The client made significant and high monetary value } \\
\text { transactions with its related parties }\end{array}$ & 0.050 & 0.427 & 0.165 & 0.640 \\
\hline 8 & $\begin{array}{l}\text { The client's executive management bonuses are tied } \\
\text { to achieving difficult operational profit or share price } \\
\text { targets }\end{array}$ & 0.097 & 0.292 & 0.712 & 0.293 \\
\hline 9 & $\begin{array}{l}\text { The client's management insists on achieving difficult } \\
\text { targets regarding profits or share prices or market } \\
\text { share }\end{array}$ & 0.318 & 0.315 & 0.668 & 0.233 \\
\hline 10 & $\begin{array}{l}\text { The client's financial reporting includes a large } \\
\text { degree of use of estimates and personal judgement }\end{array}$ & 0.325 & 0.187 & 0.016 & 0.741 \\
\hline 11 & $\begin{array}{l}\text { The client made a lot of materially significant } \\
\text { transactions that do not appear to relate to its normal } \\
\text { business activities }\end{array}$ & 0.548 & 0.459 & -0.171 & 0.287 \\
\hline 12 & $\begin{array}{l}\text { The client's management does not care to support } \\
\text { ethical values in the organisation, and does not } \\
\text { communicate the importance of ethical values to } \\
\text { employees }\end{array}$ & 0.703 & -0.158 & 0.229 & 0.155 \\
\hline 13 & $\begin{array}{l}\text { The client's business transactions are complex and } \\
\text { require complex and unclear accounting treatments }\end{array}$ & 0.346 & 0.002 & 0.165 & 0.757 \\
\hline 14 & $\begin{array}{l}\text { The client suffers high and recurring operating losses } \\
\text { that significantly threaten its future as a going } \\
\text { concern }\end{array}$ & 0.117 & 0.808 & 0.075 & 0.163 \\
\hline 15 & $\begin{array}{l}\text { The members of the client's executive management } \\
\text { own a high percentage of the client's shares }\end{array}$ & 0.234 & 0.537 & 0.324 & 0.297 \\
\hline 16 & $\begin{array}{l}\text { The client faces significant difficulties in meeting the } \\
\text { conditions of debt covenants related to financial } \\
\text { figures and ratios }\end{array}$ & 0.123 & 0.658 & 0.491 & 0.002 \\
\hline 17 & $\begin{array}{l}\text { The client suffers recurring negative operating cash } \\
\text { flows that significantly threaten its future as a going } \\
\text { concern }\end{array}$ & 0.000 & 0.765 & 0.268 & 0.152 \\
\hline 18 & $\begin{array}{l}\text { The client faces significant difficulties in meeting its } \\
\text { own previously published management expectations } \\
\text { of profits or share price or market share }\end{array}$ & 0.099 & -0.064 & 0.802 & 0.064 \\
\hline 19 & $\begin{array}{l}\text { The client faces significant difficulties in meeting the } \\
\text { conditions required for listing in the financial market } \\
\text { its shares are listed on }\end{array}$ & 0.102 & 0.235 & 0.757 & 0.029 \\
\hline \multirow[t]{2}{*}{20} & $\begin{array}{l}\text { The client suffers high competition and a declining } \\
\text { market share }\end{array}$ & 0.231 & 0.430 & 0.520 & -0.185 \\
\hline & Percentage of variance explained by factor & $37.667 \%$ & $13.309 \%$ & $8.129 \%$ & $6.405 \%$ \\
\hline
\end{tabular}




\section{Modifications of Audit Programmes in the Presence of Fraud Risk Factors}

Table 2 shows the views of auditors about the nature of required modifications to audit programmes in the presence of each fraud risk factor. For each case, the respondents were asked whether the existence of the factor would lead to an increase in the quantity of audit procedures, a change in their nature, a change in their timing, and a change in the audit team by involving more experienced auditors and/or specialised individuals.

The reported results show that the relative importance of modifying the audit programmes as a result of the existence of a fraud risk factor seem to be similar to the relative importance of the fraud risk factor itself. That is, the more important the fraud risk factor, the more important is the need for modifying the audit programme. While this is expected, it is interesting to see that the Jordanian auditors generally favoured changing the nature of the audit procedures and increasing their quantity more than changing their timing or changing the audit team. These results are not very different from the findings of other international studies listed earlier (see Glover et al. 2003; Graham \& Bedard 2003; Makkawi \& Schick 2003) . Possible explanations for the lower importance of changing the timing of audit procedures and the audit team include the small size of Jordanian audit firms and the lack of reliable internal control systems in most Jordanian clients (see Abdullatif \& Al-Khadash 2010).

\section{Factor Analysis of the Fraud Risk Factors}

In this section, the findings of the study are analysed in more detail using factor analysis - analysing the correlations between large numbers of variables to define sets of variables that are highly interrelated (Hair et al. 2010). Table 3 shows the results of the factor analysis, using a rotated component matrix ${ }^{3}$, extracted using the Principal Components Analysis ${ }^{4}$ method and rotated using the Varimax ${ }^{5}$ method. Results for each fraud risk factor are based on the mean of the response for the five questions related to each individual fraud risk factor (i.e. its importance, the need to modify the audit programme in its presence by changing the nature, quantity or timing of audit procedures, or changing the audit team). To facilitate comparability, the fraud risk factors are listed in Table 3 in the same sequence as Table 2, rather than that used in the original questionnaire. The figures in the component columns show the loadings of each fraud risk factor on each component. The number of components in Table 3 was selected by the SPSS programme as these components have eigenvalues ${ }^{6}$ of greater than 1 . Table 3 also shows the percentage of variance explained by each factor. The higher the eigenvalue, the larger the percentage of variance explaned by the factor is.

Table 3 shows that the fraud risk factors can be classified into four components (factors) according to their significant characteristics. This is shown from the highest loading correlation value for each fraud risk factor on the components (marked with bold font). The four components are:

- Component 1: Fraud risk factors 1, 2, 3, 4, 5, 6, 11 and 12

- Component 2: Fraud risk factors 14, 15, 16 and 17

- Component 3: Fraud risk factors 8, 9, 18, 19 and 20

- Component 4: Fraud risk factors 7, 10 and 13

\footnotetext{
${ }^{3}$ Factor rotation is 'A mathematical way of simplifying factor analysis results so as to better identify which variables “load on” which factors’ (Zikmund et al. 2010, p594, “” in original).

4 Principal Components Analysis is 'An approach to factor analysis that considers the total variance in the data' .(Malhotra 2007, p616).

${ }^{5}$ The Varimax procedure is 'An orthogonal method of factor rotation that minimizes the number of variables with high loadings on a factor, thereby enhancing the interpretability of the factors' (Malhotra 2007, p619).

6 'The eigenvalue represents the total variance explained by each factor' (Malhotra 2007, p612).
} 
If we exclude fraud risk factor 11 (given its lowest loading value) from component 1, we can observe that all the rest of the fraud risk factors in this component have a common characteristic relating to poor management and governance by the client. Similarly, if we exclude fraud risk factor 15 from component 2 for the same reason, we can observe that all the rest of the fraud risk factors in this component have a common characteristic relating to problems with the client's financial performance. Similarly, if we exclude fraud risk factor 20 from component 3 for the same reason, we can observe that all the rest of the fraud risk factors in this component have a common characteristic relating to problems of failing to meet previously determined targets and conditions. Finally, fraud risk factors in component 4 all relate to problems with the nature of the client's business.

Therefore, the fraud risk factors used in this study can be classified into four main groups (factors). The most significant group (in terms of the amount of variance that it explains) is poor management and governance by the client, issues that were seen by the respondents as generally the most important fraud risk factors. The other groups, in order of significance, are problems in the client's financial performance, failure to meet targets and conditions, and problems related to the nature of the client's business.

\section{Effects of the Personal Background of the Respondents on their Views}

To test for the issue of effects of the personal background of the participants on their responses, the data was split several times (each time according to a different personal background variable). Mann-Whitney and Kruskal-Wallis tests ${ }^{7}$ were applied to compare means for different groups related to each personal background variable. Variables of gender of respondent and audit experience outside Jordan were omitted from this analysis due to the small size of some groups (females and those who practised auditing outside Jordan), while for some variables some groups were merged to perform the statistical tests. Due to the very large volume of data involved in these tests (600 statements in six tables), detailed results are not reported.

As for the results, few statements per variable produced statistically significant results, and many of these seemed relatively random. However there seems to be a tendency by older and more experienced auditors with higher job ranks to favour a change in the timing of audit procedures. This finding can arguably be interpreted as a result of their experience and understanding of the importance of the timing of audit procedures in achieving a more effective financial statements audit, since the existence of fraud risk factors may lead the auditor to reduce his/her reliance on internal control of the client. This may make the auditor prefer to move many audit procedures to around year-end rather than throughout the year.

\section{Conclusions}

This study surveyed views of Jordanian auditors over the relative importance of 20 fraud risk factors as indicators of the possibility of financial statement fraud, and the modifications to audit programmes necessary in the presence of each of these factors. In doing so, views were surveyed from Jordanian auditors with experience in risk analysis and audit programme design who work for the 12 largest audit firms in Jordan, 10 of whom have affiliations with international audit firms.

Results showed that almost all fraud risk factors selected were only slightly important or even unimportant as indicators of possible fraud, with the most important related to the management style, such as previous fraud allegations and/or violations of laws, and intentional

\footnotetext{
7 The Mann-Whitney test is a nonparametric alternative to the t-test . It is used to compare means of two independent groups (Black 2001). The Kruskal-Wallis test is a nonparametric alternative to the one-way analysis of variance. It is used to compare three or more independent groups (Lind, March \& Wathen, 2010). They are both used with ordinal data, such as data in questionnaires.
} 
audit scope restrictions. The least important risk factors were the difficulties and problems in the client's financial performance. The perceived importance of the suggested modifications of audit programmes was largely related to the perceived importance of the risk factor itself. In summary, it can be argued that audit firms in Jordan meet the requirements of ISA no. 240 in considering fraud risk factors and responding to their existence to only a limited degree. These findings are relatively similar to the findings of other studies conducted in Jordan about the consideration of other risks in auditing (e.g. Abdullatif \& Al-Khadash 2010, on consideration of business risks; Thnaibat \& Shunnaq 2006, on assessment of the internal audit function by external auditors).

Factors such as ownership of most shares by senior executive management members, weak internal control and accounting systems, weak monitoring by those charged with governance, and the existence of significant abnormal transactions or transactions with related parties were all seen as having relatively low importance. This might be interpreted as a result of these issues being common in the Jordanian business environment. These findings must be given more consideration, given that such factors may create a pressure and an incentive for managers to commit fraud.

Factor analysis showed that the fraud risk factors used in the study can be classified into four distinct groups, with the most significant group being the effects of poor management and governance of the client.

Comparing these findings to those of studies in other environments, the most important finding is that Jordanian auditors do not seem to place much importance on most of the fraud risk factors, in contrast to the general findings of other international studies. This includes, for example, the relatively low importance attributed to issues such as management being dominated by a few people able to override internal controls, and the impact the pressures of weak financial performance can have on giving management an incentive to commit fraud. However, the relatively small number of comparable international studies on this issue, most of which are based on data from the USA in particular, make conclusive arguments on this issue difficult. Future research in different countries is therefore potentially helpful on this issue.

It is necessary to emphasise the importance of audit firms in Jordan and similar contexts educating auditors and supervising them on the importance of dealing with fraud risk factors in a financial statement audit, since many of these may potentially cause an incentive or an opportunity to commit fraud. This is particularly important for audit firms in developing countries that are members of international audit firms and have to apply a worldwide audit methodology and programme of detailed procedures. The international audit firm should monitor the application of these procedures and continuously educate its audit members around the world as to the importance of fraud risk factors and modifying audit programmes as a result. A similar responsibility of monitoring and educating auditors and supervising their performance lies with audit associations and regulatory authorities in Jordan and other developing countries.

Avenues for future research on fraud risk factors and their effects on audit programmes include replicating this study in different contexts to explore how views of auditors in different countries (developing and more-developed) differ, why such differences exist, and how they may affect the practice of auditing. In addition, more detailed studies (in different contexts) on modifying audit programmes as a result of the presence of fraud risk factors, and the reasons for possible differences in results would be very useful in contributing to our knowledge.

It is hoped that the findings of this study will contribute to our understanding of the application of the financial statement audit in different contexts, and potentially improve the quality and effectiveness of auditing in Jordan and in similar contexts. 


\section{References}

Abdullatif, M 2003, 'The role of auditing in Jordan: An empirical study of responsibilities and expectations', PhD thesis, The University of Manchester, UK.

Abdullatif, M 2006, 'The effectiveness of audit committees in Jordanian public shareholding companies and potential company characteristics affecting it: Perceptions from auditors in Jordan', Dirasat, Administrative Sciences, vol.33, no.2, pp450-467.

Abdullatif, M \& Al-Khadash, H 2010, 'Putting audit approaches in context: The case of business risk audits in Jordan', International Journal of Auditing, vol.14, no.1, pp1-24. http://dx.doi.org/10.1111/j.1099-1123.2009.00400.x

Abdul Majid, Gul, F A \& Tsui, J S L 2001, 'An analysis of Hong Kong auditors' perceptions of the importance of selected red flag factors in risk assessment', Journal of Business Ethics, vol.32, pp263-274.

Albrecht, W S, Albrecht, C C, Albrecht, C O \& Zimbelman, M 2009, Fraud Examination, $3^{\text {rd }}$ edn, South Western Cengage Learning, Mason, $\mathrm{OH}$.

Al-Khadash, H 2010, 'The profession's examination in Jordan and its development', Almudaqqeq, no.85-86, pp6-10.

Apostolou, B A, Hassell, J M, Webber, S A \& Sumners, G E 2001, 'The relative importance of management fraud risk factors', Behavioral Research in Accounting, vol.13, pp1-24.

http://dx.doi.org/10.2308/bria.2001.13.1.1

Asare, S K \& Wright, A M 2004, 'The effectiveness of alternative risk assessment planning tools in a fraud setting', Contemporary Accounting Research, vol. 21, no.2, pp325-352. http://dx.doi.org/10.1506/L20L-7FUM-FPCB-7BE2

Bell, T B \& Carcello, J V 2000, 'A decision aid for assessing the likelihood of fraudulent financial reporting', Auditing: A Journal of Practice \& Theory, vol.19, no.1, pp169-184.

Black, K 2001, Business Statistics: Contemporary Decision Making, $3^{\text {rd }}$ edn, South-Western College Publishing, Thomson Learning, Mason, OH.

Blay, A D, Sneathen, L D \& Kizirian, T 2007, 'The effects of fraud and going-concern risk on auditors' assessments of the risk of material misstatement and resulting audit procedures', International Journal of Auditing, vol.11, no.3, pp149-163. http://dx.doi.org/10.1111/j.1099$\underline{1123.2007 .00362 . \mathrm{x}}$

Carpenter, T D 2007, 'Audit team brainstorming, fraud risk identification, and fraud risk assessment: Implications of SAS no. 99', The Accounting Review, vol.82, no.5, pp1119-1140. http://dx.doi.org/10.2308/accr.2007.82.5.1119

Cressey, D R 1953, Other People’s Money, Patterson Smith, Montclair, NJ.

Daniels, J D, Radebaugh, L H \& Sullivan, D P 2011, International Business: Environments and Operations, $13^{\text {th }}$ edn, Pearson Education, Upper Saddle River, NJ.

Eining, M M, Jones, D R \& Loebbecke, J K 1997, 'Reliance on decision aids: An examination of auditors' assessment of management fraud', Auditing: A Journal of Practice \& Theory, vol.16, pp1-19.

Elder, R J, Beasley, M S \& Arens, A A 2010, Auditing and Assurance Services: an Integrated Approach, $13^{\text {th }}$ edn, Pearson Education, Upper Saddle River, NJ.

Glover, S M, Prawitt, D F, Schultz, J J \& Zimbelman, M F 2003, 'A test of changes in auditors' fraud-related planning judgments since the issuance of SAS no. 82', Auditing: A Journal of Practice \& Theory, vol.22, no.2, pp237-251.

Graham, L \& Bedard, J C 2003, 'Fraud risk and audit planning', International Journal of Auditing, vol.7, no.1, pp55-70. http://dx.doi.org/10.1111/1099-1123.00005

Gramling, A A \& Myers, P M 2003, 'Internal auditors' assessment of fraud warning signs: Implications for external auditors', The CPA Journal, vol.73, no.6, pp20-24.

Hackenbrack, K 1993, 'The effect of experience with different sized clients on auditor evaluations of fraudulent financial reporting indicators', Auditing: A Journal of Practice \& Theory, vol.12, no.1, pp 99-110. 
Hair, J F, Black, W C, Babin, B J \& Anderson, R E 2010, Multivariate Data Analysis: A Global Perspective, $7^{\text {th }}$ edn, Pearson Education, Upper Saddle River, NJ.

Hay, D C, Knechel, W R \& Wong, N 2006, 'Audit fees: A meta-analysis of the effect of supply and demand attributes', Contemporary Accounting Research, vol.23, no.1, pp141-191. http://dx.doi.org/10.1506/4XR4-KT5V-E8CN-91GX

Hoffman, V B \& Zimbelman, M F 2009, 'Do strategic reasoning and brainstorming help auditors change their standard audit procedures in response to fraud risk?', The Accounting Review, vol. 84, no.3, pp811-837. http://dx.doi.org/10.2308/accr.2009.84.3.811

Hogan, C E, Rezaee, Z, Riley, R A \& Velury, U 2008, 'Financial statement fraud: Insights from the academic literature', Auditing: A Journal of Practice \& Theory, vol.27, no.2, pp.231-252.

Humphrey, C, Moizer, P \& Turley, S 1993, 'The audit expectations gap in Britain: An empirical investigation', Accounting and Business Research, vol.23, pp395-411.

International Financial Reporting Standards (IFRS): 2013 International Financial Reporting Standards IFRS: Consolidated Without Early Application (Blue Book), International Financial Reporting Standards (IFRS) Foundation, International Accounting Standards Board.

International Standard on Auditing No. 240 (ISA no. 240): The Auditor's Responsibilities Related to Fraud in an Audit of Financial Statements, effective December 2009, International Federation of Accountants.

International Standards on Auditing (ISA): 2012 Handbook of International Quality Control, Auditing, Review, Other Assurance, and Related Services Pronouncements, International Federation of Accountants.

Lind, D A, Marchal, W G \& Wathen, S A 2010, Statistical Techniques in Business and Economics, $14^{\text {th }}$ edn, The McGraw-Hill Companies, New York, NY..

Makkawi, B \& Schick, A 2003, ‘Are auditors sensitive enough to fraud?’, Managerial Auditing Journal, vol.18, no.6/7, pp.591-598. http://dx.doi.org/10.1108/02686900310482722

Malhotra, N K 2007, Marketing Research: An Applied Orientation, $5^{\text {th }}$ edn, Pearson Education, Upper Saddle River, NJ

McEnroe, J E \& Martens, S C 2001, ‘Auditors’ and investors’ perceptions of the expectations gap', Accounting Horizons, vol.15, no.4, pp345-358. http://dx.doi.org/10.2308/acch.2001.15.4.345

Mock, T J \& Turner, J L 2005, 'Auditor identification of fraud risk factors and their impact on audit programs', International Journal of Auditing, vol.9, no.1, pp59-77. http://dx.doi.org/10.1111/j.1099-1123.2005.00102.x

Monroe, G S \& Woodliff, D R 1994, 'An empirical investigation of the audit expectation gap: Australian evidence', Accounting and Finance, vol.34, no.1, pp47-74.

http://dx.doi.org/10.1111/j.1467-629X.1994.tb00262.x

Moyes, G D 2008, 'CPAs' perceptions of red flags used in detecting fraud', The Icfai Journal of Audit Practice, vol.5, no.1, pp47-60.

Moyes, G D, Lin, P \& Landry, R M 2005, 'Raise the red flag', Internal Auditor, vol.62, no.5, pp4751.

Porter, B, Simon, J \& Hatherly, D 2008, Principles of External Auditing, $3^{\text {rd }}$ edn, John Wiley \& Sons, Chichester.

Saunders, M, Lewis, P \& Thornhill, A 2012, Research Methods for Business Students, $6^{\text {th }}$ edn, Pearson Education, Harlow.

Shelton, S W, Whittington, O R \& Landsittel, D 2001, 'Auditing firms' fraud risk assessment practices', Accounting Horizons, vol.15, no.1, pp19-33. http://dx.doi.org/10.2308/acch.2001.15.1.19

Siam, W \& Abdullatif, M 2011, 'Fair value accounting usefulness and implementation obstacles: Views from bankers in Jordan', In Devi, S S \& Hooper, K (Eds.), Accounting in Asia, Research in Accounting in Emerging Economies, vol. 11, Bingley, Emerald Group Publishing, pp83-107. 
Smith, M, Omar, N H, Idris, S I Z S \& Baharuddin, I 2005, 'Auditors' perception of fraud risk indicators: Malaysian evidence’, Managerial Auditing Journal, vol.20, no.1, pp73-85. http://dx.doi.org/10.1108/02686900510570713

Soltani, B 2007, Auditing: An International Approach, Financial Times, Prentice Hall, Pearson Education, Harlow.

Statement on Auditing Standards No. 82 (SAS no. 82): Consideration of Fraud in a Financial Statement Audit, 1997, American Institute of Certified Public Accountants.

Statement on Auditing Standards No. 99 (SAS no. 99): Consideration of Fraud in a Financial Statement Audit, 2002, American Institute of Certified Public Accountants.

Thnaibat, A A \& Shunnaq, B K 2006, 'External auditor's assessment of the internal audit function in the light of implementation of the International Standard on Auditing No. (610): Analytical study from the point of view of the external and internal auditors in Jordan', Jordan Journal of Business Administration, vol.2, no.2, pp187-212.

Wallace, W A 1991, The Economic Role of the Audit in Free and Regulated Markets, $2^{\text {nd }}$ edn, PWS-KENT Publishing Company.

Wallace, W A 2004, 'The economic role of the audit in free and regulated markets: A look back and a look forward', Research in Accounting Regulation, vol.17, pp267-298. http://dx.doi.org/10.1016/S1052-0457(04)17012-4

World Bank 2004, Report on the Observance of Standards and Codes (ROSC): Hashemite Kingdom of Jordan: Accounting and Auditing, http://www.worldbank.org/ifa/rosc_aa_jor.pdf, accessed in 2007.

Zikmund, W G, Babin, B J, Carr, J C \& Griffin, M 2010, Business Research Methods, $8^{\text {th }}$ edn, South Western, Cengage Learning.

Zimbelman, M F 1997, 'The effects of SAS no. 82 on auditors' attention to fraud risk factors and audit planning decisions', Journal of Accounting Research, vol.35, supplement, pp75-97. http://dx.doi.org/10.2307/2491454 
AABFJ | Volume 7, no. 1, 2013 